\title{
PENGARUH DIVIDEND PER SHARE, RETURN ON EQUITY DAN NET PROFIT MARGIN TERHADAP HARGA SAHAM PERUSAHAAAN INDUSTRI MANUFAKTUR YANG TERCATAT DI BURSA EFEK INDONESIA PERIODE 2006-2010
}

\author{
Rescyana Putri Hutami
}

Fakultas Ekonomi Universitas Negeri Yogyakarta

Abstrak

\begin{abstract}
Penelitian ini bertujuan untuk mengetahui (1) Pengaruh Dividend per Share terhadap Harga Saham Perusahaan Industri Manufaktur yang tercatat di Bursa Efek Indonesia Periode 20062010. (2) Pengaruh Return on Equity terhadap Harga Saham Perusahaan Industri Manufaktur yang tercatat di Bursa Efek Indonesia Periode 2006-2010. (3) Pengaruh Net Profit Margin terhadap Harga Saham Perusahaan Industri Manufaktur yang tercatat di Bursa Efek Indonesia Periode 2006-2010. (4) Pengaruh Dividend per Share, Return on Equity dan Net Profit Margin terhadap Harga Saham Perusahaan Industri Manufaktur yang tercatat di Bursa Efek Indonesia Periode 2006-2010.

Penelitian ini merupakan penelitian ex post facto. Sampel diambil menggunakan teknik purposive sampling. Jumlah sampel sebanyak 31 perusahaan dari 152 perusahaan industri manufaktur yang tercatat di Bursa Efek Indonesia periode 2006-2010. Dengan demikian data yang dianalisis berjumlah 155 . Sebelum melakukan teknik analisis data, terlebih dahulu dilakukan uji asumsi klasik. Pengujian hipotesis pertama, kedua dan ketiga menggunakan analisis regresi linier sederhana, sedangkan untuk pengujian hipotesis keempat menggunakan analisis regresi linier berganda.
\end{abstract}

Hasil penelitian menunjukkan bahwa (1) Dividend per Share berpengaruh positif dan signifikanterhadap Harga Saham Perusahaan Industri Manufaktur yang tercatat di Bursa Efek Indonesia Periode 2006-2010 dengan $\mathrm{r}=$ $0,914, \mathrm{r}^{2}=0,836, \mathrm{t}_{\text {hitung }}=27,882>\mathrm{t}_{\text {tabel }}=1,960$. (2) Return on Equity berpengaruh positif dan signifikanterhadap Harga Saham Perusahaan Industri Manufaktur yang tercatat di Bursa Efek Indonesia Periode 2006-2010 dengan $\mathrm{r}=$ $0,451, \mathrm{r}^{2}=0,204, \mathrm{t}_{\text {hitung }}=6,256>\mathrm{t}_{\text {tabel }}=1,960$. (3) Net Profit Margin berpengaruh positif dan signifikanterhadap Harga Saham Perusahaan Industri Manufaktur yang tercatat di Bursa Efek Indonesia Periode 2006-2010 dengan $r=$ $0,543, \mathrm{r}^{2}=0,295, \mathrm{t}_{\mathrm{hitung}}=8,006>\mathrm{t}_{\text {tabel }}$ sebesar 1,960. (4) Dividend per Share, Return on Equity dan Net Profit Margin berpengaruh positif dan signifikanterhadap Harga Saham Perusahaan Industri Manufaktur yang tercatat di Bursa Efek Indonesia Periode 2006-2010 dengan R $=0,917, \mathrm{R}^{2}=0,840, \mathrm{~F}_{\text {hitung }}=264,539>\mathrm{F}_{\text {tabel }}=$ 2,67 .

Kata Kunci: Dividend per Share, Return on Equity, Net Profit Margin dan Harga Saham. 


\section{Jurnal Nominal / Volume I Nomor I / Tahun 2012}

\section{A. Pendahuluan}

\section{Latar Belakang Masalah}

Pasar modal merupakan pertemuan antara pihak yang memiliki kelebihan dana dengan pihak yang membutuhkan dana dengan cara memperjualbelikan sekuritas. Pasar modal juga bisa diartikan sebagai pasar untuk memperjualbelikan sekuritas yang umumnya memiliki umur lebih dari satu tahun, seperti saham dan obligasi (Tandelilin, 2008:13). Setiap perusahaan yang listing di Bursa Efek Indonesia atau go public pasti menerbitkan saham yang dapat dimiliki oleh setiap investor. Tetapi, harga saham sangatlah fluktuatif dan berubah-ubah, padahal pihak investor sendiri sangat ingin harga sahamnya selalu tinggi dan tidak pernah turun. Investor harus pandai-pandai dalam menganalisis harga saham tersebut karena jika salah dalam menganalisis harga saham, maka investor akan mengalami kerugian yang jumlahnya tidak sedikit. Sebelum berinvestasi, investor hendaknya tidak hanya melihat laba bersih yang didapatkan perusahaan, tetapi juga harus melakukan analisis terhadap laporan keuangan emiten. Karena pada prakteknya, masih banyak investor yang memprediksi harga saham hanya melihat labanya saja, tanpa menganalisis laporan keuangan emiten. Padahal ada banyak faktor yang mempengaruhi harga saham. Menurut Fakhruddin dan Hadianto (2001: 101) beberapa faktor yang mempengaruhi harga saham yaitu Dividend per Share,Return on Equity dan Net Profit Margin.

Dividend per Share (DPS) adalah total dividen yang akan dibagikan pada investor untuk setiap lembar saham. DPS yang tinggi mencerminkan perusahaan memiliki prospek yang baik karena dapat membayarkan DPS dalam jumlah yang tinggi. Hal ini akan menarik investor untuk membeli saham perusahaan tersebut. Dengan banyaknya saham yang dibeli mengakibatkan harga saham perusahaan tersebut naik (Taranika Intan, 2009: 21).

Return on Equity (ROE) adalah rasio penting bagi para pemilik dan pemegang saham karena rasio tersebut menunjukkan kemampuan perusahaan dalam mengelola modal dari pemegang saham untuk mendapatkan laba bersih (Lestari, Lutfi dan Syahyunan, 2007: 5). Sedangkan menurut Chrisna (2011: 34) kenaikanReturn on Equity biasanya diikuti oleh kenaikan harga saham perusahaan tersebut. Semakin tinggi ROE berarti semakin baik kinerja perusahaan dalam mengelola modalnya untuk menghasilkan keutungan bagi pemegang saham.

Net Profit Margin (NPM)merupakan rasio yang menunjukkan seberapa besar persentase laba bersih yang diperoleh dari setiap penjualan (Rinati, 2001: 75). Rasio ini menginterpretasikan tingkat efisiensi perusahaan, yakni sejauh mana kemampuan perusahaan menekan biaya-biaya operasionalnya pada periode tertentu. Semakin besar rasio ini semakin baik karena kemampuan perusahaan dalam mendapatkan laba melalui penjualan cukup tinggi serta kemampuan perusahaan dalam menekan biaya-biayanya cukup baik. Sebaliknya, jika rasio ini semakin turun maka kemampuan perusahaan dalam mendapatkan laba melalui penjualan dianggap cukup rendah. Selain itu, kemampuan perusahaan dalam menekan biayabiayanya dianggap kurang baik sehingga investor pun enggan untuk menanamkan dananya. Hal tersebut mengakibatkan harga saham perusahaan ikut mengalami penurunan (Ardin Sianipar, 2005: 37).

Industri manufaktur merupakan salah satu primary sector di Bursa Efek Indonesia sehingga industri ini lebih mencerminkan keadaan pasar mod- 


\section{Jurnal Nominal / Volume I Nomor I / Tahun 2012}

al. Banyak investor yang lebih senang menginvestasikan dananya pada perusahaan industri manufakturkarena harga saham perusahaan industri manufaktur meningkat setiap tahun (www.idx.co.id). Tetapi harga saham industri manufaktur sangat fluktuatif dan sulit diprediksi. Selain itu, harga saham industri manufaktur sangat rentan terhadap keadaan ekonomi Indonesia. Seperti tahun 2008 yang lalu ketika terjadi krisis global yang membuat harga saham perusahaan industri manufaktur mengalami penurunan. Penurunan harga saham tersebut diakibatkan karena meningkatnya inflasi dari $6,59 \%$ menjadi $11,06 \%$ serta tingkat suku bunga pun mengalami peningkatan.

Kenaikan inflasi tersebut menyebabkan kenaikan harga bahan baku serta kenaikan biaya operasional. Selain itu, kenaikan inflasi ini menyebabkan tingkat suku bunga juga mengalami peningkatan sehingga investor lebih senang menginvestasikan dananya pada deposito daripada berinvestasi di pasar modal. Daya beli masyarakat pun semakin menurun ketika terjadi krisis global dan menimbulkan penurunan penjualan pada perusahaan industri manufaktur. Penurunan penjualanyang diiring dengan meningkatnya harga bahan baku dan biaya operasional tersebut mengakibatkan laba bersih sebagian besar perusahaan industri manufaktur ikut mengalami penurunan (Suyoto, 2010: 19). Dengan menurunnya laba ini, dividen yang dibayarkan pada pemegang saham pun akan menurun bahkan ada perusahaan industri manufaktur lebih memilih menahan labanya dan tidak membayarkan dividennya, seperti PT Mandom Indonesia Tbk dan PT Gajah Tunggal Prakarsa Tbk (www.idx.co.id). Penurunan laba tersebut turut menyebabkan penurunan pada rasio keuangan seperti DPS, ROE serta NPM pada perusahaan industri manufaktur yang diikuti dengan penurunan harga saham perusahaan industri manufaktur. Dengan diketahuinya DPS, ROE dan NPM maka dapat digunakan sebagai dasar investor dalam memilih waktu yang tepat untuk membeli maupun menjual saham. Jika nilai DPS, ROE dan NPM perusahaan industri manufaktur tersebut turun maka investor pun akan mengurungkan niatnya untuk membeli saham tersebut sehingga menyebabkan permintaan saham pada perusahaan industri manufaktur menjadi turun dan harga sahamnya pun mengalami penurunan, seperti kasus tahun 2008. Oleh karena itu, investor pun diharapkan harus pandai-pandai dalam menganalisis faktor-faktor yang diduga berpengaruh terhadap harga saham perusahaan industri manufaktur agar terhindar dari kerugian. Investor hendaknya menganalisis rasio-rasio seperti DPS, ROE serta NPM untuk memprediksi harga saham.

Tujuan penelitian ini adalah untuk mengetahui pengaruh DPS, ROE dan NPM terhadap Harga Saham Perusahaan Industri Manufaktur yang Tercatat di Bursa Efek Indonesia Periode 2006-2010.

\section{Kajian Literatur}

\section{a. Harga Saham}

\section{1) Pengertian Harga Saham}

Menurut Sunariyah (2004: 128) harga saham adalah harga selembar saham yang berlaku dalam pasar saat ini di bursa efek. Menurut Jogiyanto (2008: 143) harga saham adalah harga yang terjadi di pasar bursa pada saat tertentu yang ditentukan oleh pelaku pasar dan ditentukan oleh permintaan dan penawaran saham yang bersangkutan di pasar modal.

Menurut Suad Husnan dan Enny Pudjiastuti (2004: 151) harga saham merupakan nilai 


\section{Jurnal Nominal / Volume I Nomor I / Tahun 2012}

sekarang (present value) dari penghasilanpenghasilan yang akan diterima oleh pemodal dimasa yang akan datang. Dapat disimpulkan harga saham adalah harga selembar saham yang terjadi pada saat tertentu yang ditentukan oleh permintaan dan penawaran di pasar modal.

\section{2) Macam-Macam Harga Saham}

Menurut Sawidji Widoatmojo (2005: 91) harga saham dapat dibedakan menjadi tiga, yaitu:

a) Harga Nominal

Harga nominal adalah harga yang tercantum dalam sertifikat saham yang ditetapkan oleh emiten untuk menilai setiap lembar saham yang dikeluarkan.

b) Harga Perdana

Harga perdana adalah harga yang didapatkan pada waktu harga saham tersebut dicatat di bursa efek.

c) Harga pasar

Harga pasar adalah harga jual dari investor yang satu dengan investor yang lain.

\section{3) Penilaian Harga Saham}

a) Nilai Buku

Nilai buku per lembar saham adalah nilai aktiva bersih yang dimiliki oleh pemegang saham dengan memiliki satu lembar saham

b) Nilai Pasar

Nilai pasar adalah nilai saham di pasar, yang ditunjukkan oleh harga saham tersebut di pasar

c) Nilai Intrinsik

Nilai intrinsik atau dikenal dengan nilai teoritis merupakan nilai saham yang sebenarnya atau seharusnya terjadi. Dalam membeli atau menjual saham investor harus membandingkan nilai intrinsik dengan nilai pasar saham yang bersangku- tan sehingga investor harus mengerti cara menghitung nilai intrinsik suatu saham.Jika nilai pasar lebih besar dari nilai instrinsiknya, maka saham tersebut lebih baik dijual, tetapi jika nilai pasar lebih kecil dari nilai instrinsik, maka saham tersebut lebih baik dibeli. Dalam menentukan nilai intrinsik terdapat dua pendekatan. Kedua pendekatan tersebut adalah pendekatan nilai sekarang dan pendekatan rasio harga terhadap earning (Price Earning Ratio/PER).

\section{(1) Pendekatan Nilai Sekarang}

Perhitungan nilai saham dilakukan dengan mendiskontokan semua aliran kas yang diharapkan di masa depan dengan tingkat diskonto sebesar tingkat return yang diisyaratkan.

Aliran kas yang akan diterima investor adalah earning yang dibagikan dalam bentuk dividen. Penentuan nilai saham (pendekatan nilai sekarang) dengan menggunakan komponen dividen dapat dilakukan menggunakan model diskonto dividen. Model diskonto dividen merupakan model untuk menentukan estimasi harga saham dengan mendiskontokan semua aliran dividen yang akan diterima di masa depan. Model tersebut dapat dirumuskan sebagai berikut:

Keterangan:

$$
\widehat{P}_{0}=\frac{D_{1}}{(1+k)}+\frac{D_{2}}{(1+k)^{2}}+\cdots+\frac{D_{3}}{(1+k)^{3}}+\cdots+\frac{D_{\infty}}{(1+k)^{\infty}}
$$

$$
\widehat{P}_{0}=\text { nilai intrinsik saham dengan }
$$
model diskonto dividen

$$
D_{1}, D_{2}, \ldots D_{\infty} \quad=\text { dividen yang akan }
$$

diterima di masa depan

$$
\mathrm{k}=\text { return yang diisyaratkan }
$$

(Tandelilin, 2008: 184-186) 


\section{Jurnal Nominal / Volume I Nomor I / Tahun 2012}

Persamaan tersebut menandakan bahwa aliran dividen yang diterima investor merupakan aliran dividen yang tidak terbatas dan konstan. Padahal kenyataannya, perusahaan membayar dividen dengan jumlah yang tidak konstan atau pembayarannya mengalami pertumbuhan. Untuk itu diperlukan beberapa model perhitungan dalam mengatasi hal tersebut, yaitu:

(a) Model Pertumbuhan Nol.

Model ini berasumsi bahwa dividen yang dibayarkan tidak akan mengalami pertumbuhan. Jumlah dividen yang dibayarkan akan tetap dari waktu ke waktu. Berikut ini cara menghitung nilai saham dengan model pertumbuhan nol:

$$
\widehat{P}_{0}=\frac{D}{k}
$$

Keterangan:

$\widehat{P}_{0}$

$=$ nilai intrinsik saham dengan model diskonto dividen pertumbuhan nol.

$\mathrm{D}=$ dividen yang akan diterima dalam jumlah konstanta selama periode pembayaran dividen di masa depan.

$\mathrm{k}=\quad$ tingkat return yang diisyaratkan investor

(Tandelilin, 2008: 187)

(b) Model Pertumbuhan Konstan

Model ini dipakai untuk menentukan nilai saham jika dividen yang akan dibayarkan mengalami pertumbuhan secara konstan selama waktu tak terbatas. Berikut ini cara untuk menghitung nilai saham menggunakan model pertumbuhan konstan:

$\hat{P}_{0}=\frac{D_{0}(1+\mathrm{g})}{(1+k)}+\frac{D_{0}(1+\mathrm{g})^{2}}{(1+k)^{2}}+\frac{D_{3}(1+\mathrm{g})^{3}}{(1+k)^{3}}+\cdots+\frac{D_{\infty}(1+\mathrm{g})^{\infty}}{(1+k)^{\infty}}$

Keterangan:
$\widehat{P}_{0}=$ nilai intrinsik saham dengan model diskonto dividen pertumbuhan konstan

$$
\begin{aligned}
& D_{0}=\text { dividen yang diterima saat ini } \\
& \mathrm{k} \quad=\text { return yang diisyaratkan } \\
& \mathrm{g} \quad=\text { tingkat pertumbuhan dividen }
\end{aligned}
$$

(Tandelilin, 2008: 187)

(c) Model Pertumbuhan Tidak Konstan (Ganda) Ada kalanya perusahaan tumbuh secara pesat dan sangat baik sehingga memungkinkan untuk membayarkan dividen pada tingkat pertumbuhan yang sangat bagus selama beberapa tahun. Tetapi, perusahaan tersebut juga dapat mengalami penurunan yang cepat sehingga memungkinkan untuk membayar dividen pada tingkat penurunan tertentu. Model pertumbuhan tidak konstan ini lah yang dapat membantu investor dalam menghitung nilai intrinsik dengan pertumbuhan dividen yang tidak konstan.

$$
\widehat{P}_{0}=\sum_{t=1}^{n} \frac{D_{0}\left(1+\mathrm{g}_{t}\right)^{t}}{(1+k)^{t}}+\frac{D_{n}\left(1+\mathrm{g}_{c}\right)}{k-\mathrm{g}_{c}} \frac{1}{(1+k)^{n}}
$$

Keterangan:

$\widehat{P}_{0}$

$=$ nilai intrinsik saham dengan model pertumbuhan tidak konstan (ganda)

$\mathrm{n}=$ jumlah tahun selama periode pembayaran dividen supernormal

$\mathrm{D}_{0}=$ dividen saat ini (tahun pertama)

$\mathrm{g}_{\mathrm{t}}=$ pertumbuhan dividen supernormal

$\mathrm{D}_{\mathrm{n}}=$ dividen pada akhir tahun pertumbuhan dividen supernormal

$\mathrm{g}_{\mathrm{c}}=$ pertumbuhan dividen yang konstan

$\mathrm{k}=$ tingkat return yang diisyaratkan investor

(Tandelilin, 2008: 189-190) 
Jurnal Nominal / Volume I Nomor I / Tahun 2012

(2) Pendekatan PER

Dalam pendekatan PER atau sering disebut dengan pendekatan multiplier, investor akan menghitung berapa kali (multiplier) nilai earning yang tercermin dalam harga suatu saham. PER menggambarkan rasio atau perbandingan antara harga saham terhadap earning perusahaan. PER dapat dihitung dengan rumus:

$\mathrm{PER}=\frac{\text { Harga per lembar saham }}{\text { Earning per lembar saham }}$

(Tandelilin, 2008: 192)

\section{Analisis Saham}

a) Analisis Teknikal

Analisis teknikal adalah metode untuk memprediksi pergerakan harga dan tren pasar di masa depan melalui studi grafik historis dengan pertimbangan harga dan volume perdagangan (Sunariyah, 2004: 168).

b) Analisis Fundamental

\section{1) Analisis Ekonomi}

Analisis ekonomi adalah salah satu dari tiga analisis yang perlu dilakukan investor dalam penentuan keputusan investasinya. Analisis ekonomi perlu dilakukan karena kecenderungan adanya hubungan yang kuat antara apa yang terjadi pada lingkungan ekonomi makro dan kinerja suatu pasar modal (Tandelilin, 2008: 210).

2) Analisis Industri.

Analisis industri merupakan tahap penting yang perlu dilakukan investor karena analisis tersebut dapat membantu investor dalam mengidentifikasikan peluang-peluang investasi dalam industri yang mempunyai karakteristik risiko dan return yang menguntungkan investor. Analisis industri diperlukan untuk mem- ilihindustri yang memilikiprospek yang menguntungkan.

3) Analisis Perusahaan

Tahapan analisis perusahaan bertujuan untuk mengetahui perusahaan yang paling berprospek dan paling menguntungkan.

\section{Faktor Yang Mempengaruhi Harga Saham}

Menurut Fakhruddin dan Hadianto (2001: 101) faktor-faktor yang mempengaruhi harga saham yaitu:

\section{a) Dividend per Share}

Dividend per Share merupakan total semua dividen tunai yang dibagikan kepada pemegang saham dibandingkan dengan jumlah saham yang beredar (Weston dan Copeland, 2001:325).

$$
\text { DPS }=\frac{\text { Dividen Tunaĩ }}{\text { Jumlah Saham Beredar }}
$$

(Weston dan Copeland, 2001:326)

Menurut Gibson (2003: 116), salah satu alasan investor membeli saham adalah untuk mendapatkan dividen. Investor mengharapkan dividen yang diterimanya dalam jumlah besar dan mengalami peningkatan setiap periode. DPS yang tinggi mencerminkan perusahaan memiliki prospek yang baik dan akan menarik minat investor yang memanfaatkan dividen untuk keperluan konsumsi. Apabila DPS yang diterima naik tentu saja hal ini akan membuat investor tertarik untuk membeli saham perusahaan tersebut. Dengan banyaknya saham yang dibeli maka harga saham perusahaan tersebut akan naik di pasar modal (Sutrisno, 2003: 305). Hasil penelitian Cerpen Naibaho (2010) menunjukkan bahwa Dividend per Share (DPS) berpengaruh terhadap Harga Saham. Oleh karena 
Jurnal Nominal / Volume I Nomor I / Tahun 2012

itu, hipotesis penelitian berikut dikemukakan:

$\mathrm{Ha}_{1}$ : Dividend per Share (DPS) berpengaruh positif terhadap Harga Saham Perusahaan Industri Manufaktur yang tercatat di Bursa Efek Indonesia periode 2006-2010.

\section{b) Return on Equity}

Menurut Nurmalasari (2002: 79) Return on Equity (ROE) merupakan salah satu alat utama investor yang paling sering digunakan dalam menilai suatu saham.

\section{ROE $=\frac{\text { Laba Bersih setelah bunga dan pajak }}{\text { Jumlah Modal Sendiri }}$}

(Tandelilin, 2008: 240)

Menurut Chrisna (2011: 34) kenaikan Return on Equity biasanya diikuti oleh kenaikan harga saham perusahaan tersebut. Semakin tinggi ROE berarti semakin baik kinerja perusahaan dalammengelola modalnya untuk menghasilkan keuntungan bagi pemegang saham. Dapat dikatakan bahwa perusahaan tersebut dapat menggunakan modal dari pemegang saham secara efektif dan efisien untuk memperoleh laba. Dengan adanya peningkatan laba bersih maka nilai ROE akan meningkat pula sehingga para investor tertarik untuk membeli saham tersebut yang akhirnya harga saham perusahaan tersebut mengalami kenaikan. Hasil penelitian Cerpen Naibaho (2010) menunjukkan bahwa Return on Equity (ROE) berpengaruh terhadap harga saham. Oleh karena itu, hipotesis penelitian berikut dikemukakan:

$\mathrm{Ha}_{2}$ : Return on Equity (ROE) berpengaruh positif terhadap Harga Saham Perusahaan Industri Manufaktur yang tercatat di Bursa Efek Indonesia Periode 2006-2010.

\section{c) Net Profit Margin}

Menurut Rinati (2001: 75) NPM menunjukkan berapa besar persentase laba bersih yang diperoleh dari setiap penjualan.

Net Profit Margin $(\mathrm{NPM})=\frac{\text { Laba Bersih Setelah Pajak }}{\text { Penjualan Bersih }}$

(Tandelilin, 2008: 239)

NPM yang tinggi dapat menunjukkan kinerja perusahaan yang bagus karena dapat menghasilkan laba bersih yang besar melalui aktivitas penjualannya sehingga saham perusahaan tersebut banyak diminati investor dan akan menaikkan harga saham perusahaan tersebut (Ardin Sianipar, 2005: 37). Hasil penelitian Santy Sitohang (2010) juga menunjukkan bahwa Net Profit Margin berpengaruh terhadap harga saham. Oleh karena itu, hipotesis penelitian berikut dikemukakan:

$\mathrm{Ha}_{3}$ : Net Profit Margin (NPM) berpengaruh positif terhadap Harga Saham Perusahaan Industri Manufaktur yang tercatat di Bursa Efek Indonesia Periode 2006-2010.

\section{B. Metode Penelitian}

\section{Populasi dan Sampel}

Populasi yang digunakan dalam penelitian ini adalah seluruh perusahaan industri manufaktur yang go public dan aktif di Bursa Efek Indonesia selama tahun 2006-2010 sejumlah 152 perusahaan.Sedangkan teknik penarikan sampel yang digunakan adalah purposive sampling.Perusahaan yang memenuhi kriteria sampel adalah 31 perusahaan dengan jumlah observasi sebanyak 155 buah. Penelitian ini menggunakan studi empiris yang dilakukan pada perusahaan-perusahaan yang listing di Bursa Efek Indonesia periode 2006-2010. 
Jurnal Nominal / Volume I Nomor I / Tahun 2012

\section{Definisi Operasional}

a. Variabel dependen (Y), yaitu variabel yang menjadi akibat adanya variabel independen. Variabel dependen dalam penelitian ini adalah harga saham. Harga saham adalah harga selembar saham yang terjadi pada saat tertentu serta harganya ditentukan oleh permintaan dan penawaran di pasar modal. Harga saham yang digunakan peneliti yaitu harga saham pada harga penutupan (closing price) tiap akhir tahun 2006-2010 karena merupakan harga saham yang tertera di laporan keuangan perusahaan pada tiap akhir tahun.

b. Variabel Independen (X), yaitu variabel yang mempengaruhi variabel dependen. Variabel independen dalam penelitian adalah:

\section{(1) Dividend per Share (DPS)}

DPS adalah total semua dividen tunai yang dibagikan dibandingkan dengan jumlah saham yang beredar. Nilai DPS dalam penelitian ini diambil dari laporan keuangan akhir tahun (pada tanggal 31 Desember) yang menunjukkan perusahaan industri manufaktur melakukan pembagian dividen atau tidak selama satu tahun dalam waktu periode penelitian. DPS di dalam penelitian ini dinyatakan dengan simbol $\mathrm{X}_{1}$. DPS dihitung dengan menggunakan rumus:

\section{DPS $=\frac{\text { Dividen Tunai }}{\text { Jumlah Saham Beredar }}$}

\section{(2) Return on Equity (ROE)}

ROE merupakan suatu alat analisis untuk mengukur sejauh mana kemampuan perusahaan dalam menghasilkan keuntungan bagi pemilik saham atas modal yang telah mere- ka investasikan. ROE di dalam penelitian ini dinyatakan dengan simbol X2. Nilai ROE dapat diperoleh dengan menggunakan rumus:

\section{ROE $=\frac{\text { Laba Bersih setelah bunga dan pajak }}{\text { Jumlah Modal Sendiri }}$}

\section{(c) Net Profit Margin (NPM)}

Net Profit Margin (NPM) adalah rasio yang digunakan untuk mengukur laba bersih yang dihasilkan oleh setiap penjulaan. NPM di dalam penelitian ini dinyatakan dengan simbol $\mathrm{X}_{3}$. Nilai NPM dapat diperoleh dengan menggunakan rumus:

$$
\mathrm{NPM}=\frac{\text { Laba Bersih Setelah Pajak }}{\text { Penjualan Bersih }}
$$

\section{Metode Pengumpulan Data}

Metode pengumpulan data yang dilakukan untuk mengumpulkan data dalam penelitian ini adalah metode dokumentasi. Metode dokumentasi menuntut adanya pengamatan dari peneliti baik secara langsung maupun tidak langsung terhadap objek yang diteliti dengan menggunakan instrumen berupa pedoman penelitian dalam bentuk lembar pengamatan atau lainnya. Metode ini dilakukan dengan mengumpulkan data dari Bursa Efek Indonesia dan Indonesian Capital Market Directory (ICMD), jurnal-jurnal, artikel-artikel, tulisantulisan ilmiah dan catatan dari media cetak maupun elektronik. Data yang dikumpulkan adalah data harga saham (closing price) perusahaan industri manufaktur tahun 2006-2010 serta data Dividend per Share, Return on Equitydan Net Profit Margin.

\section{Teknik Analisis Data}

Teknik analisis data dalam penelitian ini 
Jurnal Nominal / Volume I Nomor I / Tahun 2012

menggunakan teknik analisis regresi linier sederhana dan analisis regresi linier berganda (multiple linier regression). Secara teoritis model regresi tersebut akan menghasilkan nilai parameter model praduga yang sahih dan BLUE (Best Linier Unbiased Estimation) bila dipenuhi uji asumsi klasik (Imam Ghozali, 2009: 25).

\section{1) Uji Asumsi Klasik}

\section{a) Uji Multikolinieritas}

Untuk mengetahui multikolinearitas dapat dilihat dari nilai tolerance dan Variance Inflation Factor (VIF). Nilai yang umum dipakai adalah nilai tolerance sebesar 0,1 atau sama dengan nilai VIF sebesar 10.

$\mathrm{VIF}=\frac{1}{1-R^{2}}$ atau $\mathrm{VIF}=\frac{1}{\text { Tolerance }}$ (Imam Ghozali, 2006: 96)

Jika VIF $>10$ atau jika tolerance $<0,1$ maka ada multikolinieritas dalam model regresi.

\section{b) Uji Autokorelasi}

Gejala autokorelasi dapat dideteksi dengan menggunakan uji Durbin-Watson (DW). Uji ini menghasilkan DW hitung (d) dan nilai DW tabel $\left(d_{L}\right.$ dan $\left.d_{u}\right)$. Pengambilan keputusan ada tidaknya autokorelasi melalui kriteria DW tabel dengan tingkat signifikansi 5\% yaitu sebagai berikut:

$0<\mathrm{d}<\mathrm{d}_{\mathrm{L}}=$ Ada autokorelasi

$\mathrm{d}_{\mathrm{L}} \leq \mathrm{d} \leq \mathrm{d}_{\mathrm{u}}=$ Tanpa Kesimpulan

$4-\mathrm{d}_{\mathrm{L}}<\mathrm{d}<4=$ Ada autokorelasi

$4-\mathrm{d}_{\mathrm{u}} \leq \mathrm{d} \leq 4-\mathrm{d}_{\mathrm{L}} \quad=$ Tanpa Kesimpulan

$\mathrm{d}_{\mathrm{u}}<\mathrm{d}<4-\mathrm{d}_{\mathrm{u}} \quad=$ Tidak ada autokorelasi

(Imam Ghozali, 2006: 100) c) Uji Normalitas

Uji normalitas data dalam penelitian ini menggunakan uji grafik normal plot. Titiktitik yang terbentuk harus menyebar disekitar garis diagonal serta arah penyebarannya mengikuti arah garis diagonal, bila tidak maka data yang tersedia tidak terdistribusinormal (Imam Ghozali, 2006: 149).

\section{d) Uji Heteroskedastisitas}

Pada penelitian ini untuk menguji ada atau tidaknya heteroskedastisitas dengan melihat grafik plot antara prediksi variabel dependen (ZPRED) dengan residualnya (SRESID). Deteksi ada tidaknya heteroskedastisitasdilakukan dengan melihat ada tidaknya pola tertentu pada grafik scatterplot antara SRESID dan ZPRED. Jika penyebarannya tidak berbentuk pola tertentu maka tidak terjadi heteroskedastisitas (Imam Ghozali, 2006: 125).

Menurut Imam Ghozali (2006: 126) dasar pengambilan keputusan uji tersebut yaitu sebagai berikut:

I. Jika ada pola tertentu seperti titik-titik yang ada membentuk pola tertentu yang teratur (bergelombang, melebar kemudian menyempit) maka mengindikasikan telah terjadi heteroskedasitas.

II. Jika tidak ada pola yang jelas serta titik-titik menyebar di atas dan di angka 0 pada sumbu Y maka tidak terjadi heteroskedasitas.

\section{e) Uji Linearitas}

Uji linieritas dapat menggunakan 
Jurnal Nominal / Volume I Nomor I / Tahun 2012

tabel Anova dengan mencari nilai Devia-

tion From Linearity dari uji F linier. Jika

angka pada Deviation From Linearity

lebih besar dari $0,05(\mathrm{P}>0,05)$, berarti

hubungan antara variabel dependen

dengan variabel independen adalah linier

(Joko Sulistyo, 2010: 54-56).

\section{2) Pengujian Hipotesis}

\section{a) Analisis Regresi Linier Sederhana}

Analisis ini digunakan untuk mengetahui pengaruh DPS terhadap harga saham, pengaruh ROE terhadap harga saham dan pengaruh NPM terhadap harga saham dengan model persamaan regresi sebagai berikut:

$$
\mathrm{Y}=\mathrm{aX}+\mathrm{K}
$$

Keterangan:

$$
\begin{array}{ll}
\mathrm{Y} & =\text { kriterium } \\
\mathrm{a} & =\text { bilangan koefisien } \\
\mathrm{X} & =\text { prediktor }
\end{array}
$$

\section{Hasil dan Pembahasan}

\section{Tabel Statistik Deskriptif}

\begin{tabular}{|lr|r|r|r|}
\hline \multicolumn{5}{|c|}{ Statistics } \\
\hline & HargaSaham & \multicolumn{1}{c|}{ DPS } & \multicolumn{1}{c|}{ ROE } & \multicolumn{1}{c|}{ NPM } \\
\hline Mean & 14871.69 & \multicolumn{1}{c|}{898.5074} & .247192 & .091482 \\
\hline Median & 2200.00 & 70.0000 & .188000 & .075600 \\
\hline Mode & $900^{\mathrm{a}}$ & 30.00 & & - \\
\hline Std. Deviation & 39586.183 & 2797.04912 & .3031027 & .0687846 \\
\hline Variance & $1.567 \mathrm{E} 9$ & 7823483.767 & .092 & .005 \\
\hline Range & 383942 & 21278.00 & 3.2399 & .3120 \\
\hline Minimum & 58 & 1.00 & .0001 & .0007 \\
\hline Maximum & 384000 & 21279.00 & 3.2400 & .3127 \\
\hline Sum & 2305112 & 139268.65 & 38.3148 & 14.1797 \\
\hline
\end{tabular}

(Sutrisno Hadi, 2004: 5)

\section{b) Analisis Regresi Linier Berganda}

Analisis regresi linear berganda digunakan untuk menguji pengaruh variabel independen secara bersamasama (simultan) terhadap variabel dependen. Model persamaan regresi linier berganda sebagai berikut:

$\mathrm{Y}=\mathrm{a}_{1} \mathrm{X}_{1}+\mathrm{a}_{2} \mathrm{X}_{2}+\mathrm{a}_{3} \mathrm{X}_{3}+\mathrm{K}$

Keterangan:

$$
\begin{array}{ll}
\mathrm{Y} & =\text { kriterium } \\
\mathrm{X}_{1} & =\text { prediktor } 1 \\
\mathrm{X}_{2} & =\text { prediktor } 2 \\
\mathrm{X}_{3} & =\text { prediktor } 3 \\
\mathrm{a}_{1} & =\text { koefisien prediktor } 1 \\
\mathrm{a}_{2} & =\text { koefisien prediktor } 2 \\
\mathrm{a}_{3} & =\text { koefisien prediktor } 3 \\
\mathrm{~K} & =\text { bilangan konstanta }
\end{array}
$$

(Sutrisno Hadi, 2004: 18) 


\section{Jurnal Nominal / Volume I Nomor I / Tahun 2012}

Dari hasil tabel desktiptif di atas menunjukkan bahwa untuk variabel Harga Saham (Y) diperoleh nilai tertinggi sebesar Rp. 384.000 dan nilai terendah sebesar Rp. 58. Selain itu juga didapatkan nilai mean (M) sebesar 14.871,69, median (Me) sebesar 2.200, mode (Mo) sebesar 900 serta standar deviasi (SD) sebesar 39.586,183.

Dari hasil tabel desktiptif di atas menunjukkan bahwa untuk variabel Dividend per Share $\left(\mathrm{X}_{1}\right)$ diperoleh nilai tertinggi sebesar 21.279 dan nilai terendah sebesar 1. Selain itu juga didapatkan nilai mean (M) sebesar 889,5074, median (Me) sebesar 70, mode (Mo) sebesar 30 serta standar deviasi (SD) sebesar 2.797,04912.

Dari hasil tabel desktiptif di atas menunjukkan bahwa untuk variabel Return on Equity $\left(\mathrm{X}_{2}\right)$ diperoleh nilai tertinggi sebesar 3,2400 dan nilai terendah sebesar 0,0001. Selain itu juga didapatkan nilai mean (M) sebesar 0,247192, median (Me) sebesar 0,188, tidak terdapat mode (Mo) serta standar deviasi (SD) sebesar 0,3031027.

Dari hasil tabel desktiptif di atas menunjukkan bahwa untuk variabel Net Profit Margin $\left(\mathrm{X}_{3}\right)$ diperoleh nilai tertinggi sebesar 0,3127 dan nilai terendah sebesar 0,0007 . Selain itu juga didapatkan nilai mean (M) sebesar 0,091482, median (Me) sebesar 0,075600 tidak terdapat mode (Mo) serta standar deviasi (SD) sebesar 0,0687846.

\section{A) Uji Multikolinieritas}

\begin{tabular}{|l|l|l|l|}
\hline $\begin{array}{c}\text { Var- } \\
\text { iabel }\end{array}$ & VIF & $\begin{array}{l}\text { Toler- } \\
\text { ance }\end{array}$ & Kesimpulan \\
\hline DPS & 1,683 & 0,594 & $\begin{array}{l}\text { Tidak terjadi multiko- } \\
\text { linieritas }\end{array}$ \\
\hline ROE & 1,697 & 0,589 & $\begin{array}{l}\text { Tidak terjadi multiko- } \\
\text { linieritas }\end{array}$ \\
\hline NPM & 1,381 & 0,724 & $\begin{array}{l}\text { Tidak terjadi multiko- } \\
\text { linieritas }\end{array}$ \\
\hline
\end{tabular}

Dari hasil pengujian tersebut dapat diketahui bahwa semua variabel independen pada model regresi tidak mengalami multikolinieritas. Hal tersebut ditunjukkan dengan nilai VIF $<10$ serta nilai tolerance $>0,1$. Dapat dikatakan bahwa model regresi tersebut layak digunakan karena tidak ditemui variabel independen yang mengalami multikolinieritas.

\section{B) Uji Autokorelasi}

\begin{tabular}{|c|c|c|c|c|c|}
\hline \multicolumn{6}{|c|}{ Model Summary $^{\mathrm{b}}$} \\
\hline & & $\mathrm{R}$ & Adjust- & Std. Error & \\
Mo & & $\begin{array}{c}\text { Squa } \\
\text { ed } \mathrm{R}\end{array}$ & $\begin{array}{c}\text { of the Esti- } \\
\text { Square }\end{array}$ & $\begin{array}{c}\text { Durbin- } \\
\text { mate }\end{array}$ & Watson \\
del & $\mathrm{R}$ & re & Squats \\
\hline 1 & $.894^{\mathrm{a}}$ & .800 & .796 & 17879.156 & 1.971 \\
\hline
\end{tabular}

Jika dilihat dari hasil perbandingan pada tingkat signifikansi 5\% diketahui nilai DW untuk $\mathrm{d}_{\mathrm{L}}$ $(a ; \mathrm{k} ; \mathrm{n})=(0,05 ; 3 ; 155)=1,6982$ dan nilai tabel untuk $d_{u}(a ; k ; n)=(0,05 ; 3 ; 155)=1,7770$. Dengan nilai DW yang sebesar 1,971 yang berada di antara $\mathrm{d}_{\mathrm{u}}<\mathrm{d}<4-\mathrm{d}_{\mathrm{u}}=1,7770<1,971<4-$ 1,7770 maka dapat disimpulkan tidak terdapat autokorelasi sehingga model regresi layak untuk digunakan.

\section{C) Uji Normalitas}

Pada penelitian ini didapat garis normal probability plot sebagai berikut: 


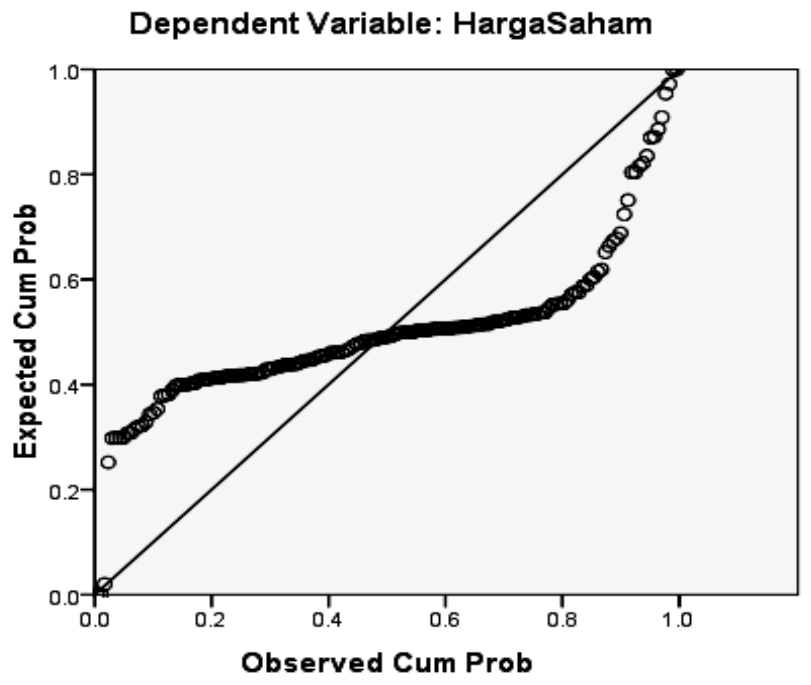

Dari garis normal probability plot, dapat disimpulkan bahwa variabel tidak terdistribusi secara normal. Hal ini dikarenakan titik-titik penyebaran data menyebar jauh dari garis diagonal serta tidak mengikuti arah garis diagonal. Sedangkan hasil pengujian menggunakan Uji Kolmogorov-Smirnov yaitu sebagai berikut:

\begin{tabular}{|l|l|r|}
\hline \multicolumn{2}{|c|}{ One-Sample Kolmogorov-Smirnov Test } \\
\hline \multirow{2}{*}{} & & $\begin{array}{c}\text { Unstandardized } \\
\text { Residual }\end{array}$ \\
\hline $\mathrm{N}$ & 155 \\
\hline $\begin{array}{l}\text { Normal } \mathrm{Pa} \text { - } \\
\text { rameters } \mathrm{a}, \mathrm{b}\end{array}$ & Mean & .0000000 \\
\cline { 2 - 3 } $\begin{array}{l}\text { Most Ex- } \\
\text { treme Dif- } \\
\text { ferences }\end{array}$ & Absolute & .272 \\
\cline { 2 - 3 } & Positive & .259 \\
\cline { 2 - 3 } & Negative & -.272 \\
\hline Kolmogorov-Smirnov Z & 3.392 \\
\hline \multicolumn{2}{|l|}{ Asymp. Sig. (2-tailed) } & .000 \\
\hline
\end{tabular}

Dari tabel di atas sudah jelas bahwa variabel-variabel dalam penelitian ini tidak terdistribusi secara normal. Hal tersebut dapat dinilai melalui nilai siginifikansi sebesar 0,000 yang diperoleh jauh lebih rendah dari nilai signifikansi yang diharapkan yaitu 0,05 . Tetapi menurut Imam Ghozali (2009: 132) model regresi masih tetap dapat digunakan jika uji normalitas diobati dengan cara tertentu. Caranya yaitu variabel dependen dan inde-
Dependent Variable: LnHargaSaham

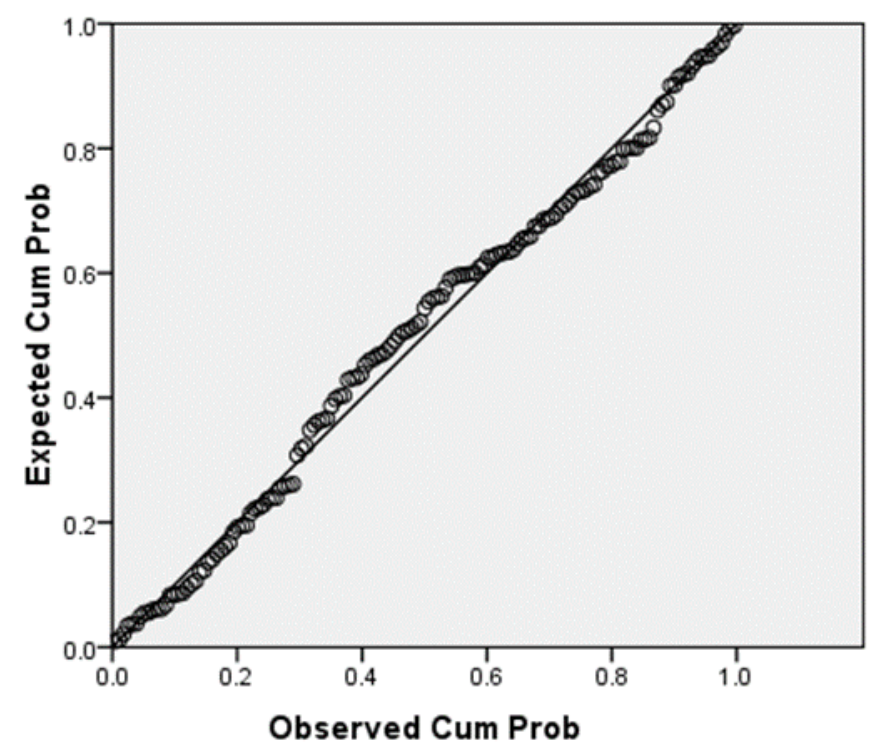

penden akan ditranformasi menjadi bentuk logaritma natural (Ln) yang diharapkan data residu dapat terpenuhi sehingga uji normalitas pun juga dapat terpenuhi. Caranya yaitu mentransformasi persamaan regresi menjadi double log atau variabel dependen dan idenpenden diubah dalam bentuk logaritma natural ( $\mathrm{Ln})$. Setelah melakukan tranformasi variabel dependen dan independen tersebut maka didapatkan grafik normal plot sebagai berikut:

Dari hasil grafik di atas dapat diketahui bahwa variabel-variabel telah terdistribusi secara normal karena titik-titik penyebaran data menyebar di sekitar garis diagonal dan mengikuti arah garis diagonal. Untuk menguatkan hasil grafik normal plot tersebut dilakukan uji Kolmogorov - Smirnov 


\section{D) Uji Heteroskedastisitas}

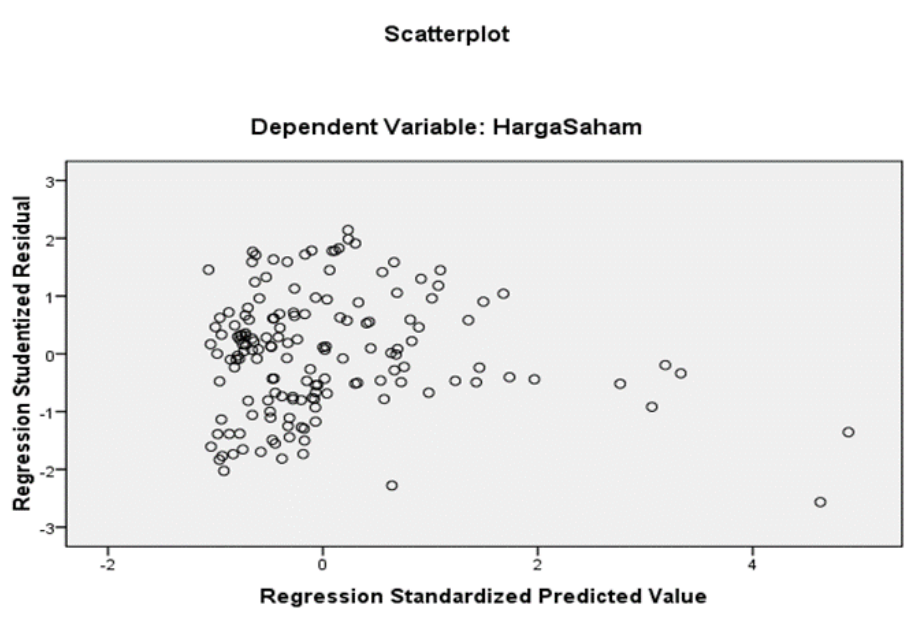

Berdasarkan gambar di atas terlihat bahwa tidak ada pola yang jelas dapat dikatakan gambar tersebut tidak membentuk suatu pola tertentu seperti pola bergelombang atau membentuk angka $U$. Titik-titik yang ada menyebar di atas dan di bawah angka 0 sehingga dapat disimpulkan bahwa model regresi yang digunakan tidak mengalami heteroskedastisitas.

\section{E) Uji Linieritas}

\begin{tabular}{|l|l|l|l|}
\hline $\begin{array}{l}\text { Variabel } \\
\text { Dependen }\end{array}$ & $\begin{array}{l}\text { V a r i a - } \\
\text { belIndepe } \\
\text { nden }\end{array}$ & $\begin{array}{l}\text { Sig. Devia- } \\
\text { tion From } \\
\text { Liniearity }\end{array}$ & $\begin{array}{l}\text { K e - } \\
\text { impul } \\
\text { an }\end{array}$ \\
\hline $\begin{array}{l}\text { Harga Sa- } \\
\text { ham }\end{array}$ & $\begin{array}{l}\text { Dividend } \\
\text { per Share }\end{array}$ & 0,724 & Linier \\
\hline & $\begin{array}{l}\text { Return on } \\
\text { Equity }\end{array}$ & 0,171 & Linier \\
\hline & $\begin{array}{l}\text { Net Profit } \\
\text { Margin }\end{array}$ & 0,154 & Linier \\
\hline
\end{tabular}

Dari tabel di atas dapat diketahui bahwa semua variable independen terhadap variable dependen memiliki hubungan yang bersifat linier. Dapat disimpulkan bahwa model analisis regresi linier dapat digunakan dalam penelitian ini.

\section{F) Uji Hipotesis Penelitian}

Berikut ini ringkasan hasil pengujian hipotesis yang dilakukan dengan menggunakan analisis regresi linier sederhana untuk pengujian hipotesis pertama, kedua dan ketiga serta menggunakan analisis regresi linier berganda untuk pengujian hipotesis keempat.

Tabel berada dihalaman berikutnya : 
Jurnal Nominal / Volume I Nomor I / Tahun 2012

\begin{tabular}{|c|c|c|c|c|c|c|c|c|c|}
\hline \multirow{2}{*}{ Variabel } & \multirow{2}{*}{$\begin{array}{l}\text { Koefisien } \\
\text { Regresi }\end{array}$} & \multirow{2}{*}{ Konstanta } & \multicolumn{2}{|c|}{ Harga } & \multicolumn{2}{|l|}{ Harga t } & \multicolumn{2}{|l|}{ Harga $F$} & \multirow{2}{*}{ Kesimpulan } \\
\hline & & & $r$ & $\mathrm{r}^{2}$ & $\mathrm{t}_{\text {hitung }}$ & $t_{\text {tabel }}$ & $\mathrm{F}_{\text {hitung }}$ & $\mathrm{F}_{\text {tabel }}$ & \\
\hline $\mathrm{X}_{1}-\mathrm{Y}$ & 0,813 & 4,261 & $\begin{array}{l}0,91 \\
4\end{array}$ & $\begin{array}{l}0,83 \\
6\end{array}$ & 27,882 & 1,976 & & & $\begin{array}{l}\text { Positifdan- } \\
\text { signifikan }\end{array}$ \\
\hline $\mathrm{X}_{2}-\mathrm{Y}$ & 0,642 & 9,167 & $\begin{array}{l}0,45 \\
1\end{array}$ & $\begin{array}{l}0,20 \\
4\end{array}$ & 6,256 & 1,976 & & & $\begin{array}{l}\text { Positifdan- } \\
\text { signifikan }\end{array}$ \\
\hline $\mathrm{X}_{3}-\mathrm{Y}$ & 1,014 & 10,739 & $\begin{array}{l}0,54 \\
3\end{array}$ & $\begin{array}{l}0,29 \\
5\end{array}$ & 8,006 & 1,976 & & & $\begin{array}{l}\text { Positifdan- } \\
\text { signifikan }\end{array}$ \\
\hline $\begin{array}{l}\mathrm{X}_{1}, \mathrm{X}_{2}, \mathrm{X}_{3^{-}} \\
\mathrm{Y}\end{array}$ & $\begin{array}{l}0,830 \mathrm{X}_{1}, \\
0,105 \mathrm{X}_{2}, \\
-0,160 \mathrm{X}_{3}\end{array}$ & 3,943 & $\begin{array}{l}0,91 \\
7\end{array}$ & $\begin{array}{l}0,84 \\
0\end{array}$ & & & $\begin{array}{l}264,53 \\
9\end{array}$ & 2,66 & $\begin{array}{l}\text { Positifdan- } \\
\text { signifikan }\end{array}$ \\
\hline
\end{tabular}

Hasil persamaan regresi sebagai berikut:

LnHargaSaham $=0,813 \operatorname{LnDPS}+4,261$

LnHargaSaham $=0,642 \operatorname{LnROE}+9,167$

LnHargaSaham = 1,014LnNPM + 10,739.

LnHargaSaham $=0,830 \operatorname{LnDPS}+0,105 \mathrm{LnROE}-0,160 \mathrm{LnNPM}+3,943$.

\section{Pembahasan}

1) Hasil penelitian ini diperkuat oleh kajian teori dan hasil penelitian yang relevan. Berdasarkan teori yang dikemukakan Purwanta dan Fakhrudin (2006: 101) faktor-faktor yang mempengaruhi harga saham yaitu terdiri dari Debt Equity Ratio, Dividend per Share, Return on Investment, Net Profit Margin, Return on Equity dan Earning per Share. Menurut Weston dan Copeland (2001: 325) Dividend per Share merupakan total semua dividen tunai yang dibagikan kepada pemegang saham dibandingkan dengan jumlah saham yang beredar. Dividend perShare digunakan untuk mengukur berapa rupiah yang diberikan kepada pemegang saham dari laba bersih perusahaan untuk setiap lembar saham. Salah satu alasan investor membeli saham adalah untuk mendapatkan dividen (Gibson, 2003: 816). Selain itu, menurut Sutrisno (2003: 305) investor mengharapkan dividen yang diterimanya dalam jumlah besar dan mengalami peningkatan setiap periode. DPS yang tinggi mencerminkan perusahaan memiliki prospek yang baik dan akan menarik investor yang memanfaatkan dividen untuk keperluan konsumsi. Apabila DPS yang diterima naik tentu saja hal ini akan menarik investor untuk membeli saham perusahaan tersebut. Dengan banyaknya saham yang dibeli maka harga saham perusahaan tersebut akan naik di pasar modal. Serta menurut Teori Signaling Hyphotesis yaitu teori yang diungkapkan oleh Rozeff (1982) yang beranggapan bahwa dividen tampaknya memiliki informasi atau sebagai isyarat akan prospek perusahaan. Apabila perusahaan meningkatkan pembayaran dividen, mungkin diartikan oleh pemodal sebagaisinyal harapan manajemen tentang akan membaiknyakinerja perusahaan di masa yang akan datang. Bhatta charya (1979) mengembangkan suatu model sinyal (signal model), bahwa tingginya dividen yang dibagikan menunjukkan tingginya performance perusahaan yang nantinya akan meningkatkan nilai perusahaan dan harga sa- 


\section{Jurnal Nominal / Volume I Nomor I / Tahun 2012}

ham perusahaan tersebut.

Selain itu, hasil penelitian ini sejalan dengan penelitian yang sebelumnya dilakukan oleh Cerpen Naibaho (2010) yang hasilnya Dividend per Share berpengaruh positifdan signifikan terhadap harga saham. Dengan demikian dapat dikatakan bahwa semakin tinggi Dividend per Share akan semakin tinggi pula harga saham dan sebaliknya jika Dividend per Share yang dibagikan kepada pemegang saham semakin rendah maka harga saham juga semakin rendah.

2) Hasil penelitian ini diperkuat oleh kajian teori dan hasil penelitian yang relevan. Berdasarkan teori yang dikemukakan Purwanta dan Fakhrudin (2006: 101) faktor-faktor yang mempengaruhi harga saham yaitu terdiri dari Debt Equity Ratio, Dividend per Share, Return on Investment, Net Profit Margin, Return on Equity dan Earning per Share. Menurut Suad Husnan dan Enny Pudjiastuti (2004: 74) Return on Equity merupakan rasio untuk mengukur seberapa banyak laba yang menjadi hak pemilik modal sendiri. Menurut Lestari, Lutfi dan Syahyunan (2007: 5), ROE merupakan rasio penting bagi para pemilik dan pemegang saham karena rasio tersebut menunjukkan kemampuan perusahaan dalam mengelola modal dari pemegang saham untuk mendapatkan laba bersih. Perusahaan yang memiliki Return on Equity yang rendah atau bahkan negatif akan terklasifikasikan sebagai perusahaan yang kurang baik dalam menghasilkan laba yang menjadi hak pemegang saham. Hal ini ditambahkan dengan teori yang diungkapkan oleh Chrisna (2011: 34)bahwa kenaikan Return on
Equity biasanya diikuti oleh kenaikan harga saham perusahaan tersebut. Semakin tinggi ROE berarti semakin baik kinerja perusahaan dalam mengelola modalnya untuk menghasilkan keuntungan bagi pemegang saham. Dapat dikatakan bahwa perusahaan tersebut dapat menggunakan modal dari pemegang saham secara efektif dan efisien untuk memperoleh laba. Dengan adanya peningkatan laba bersih maka nilai ROE akan meningkat pula sehinggapara investor tertarik untuk membeli saham tersebut maka harga saham perusahaan tersebut akan mengalami kenaikan. Teori tersebut semakin memperkuat hasil penelitian ini, yaitu Return on Equity berpengaruh positif dan signifikan terhadap Harga Saham Perusahaan Industri Manufaktur yang Tercatat di Bursa Efek Indonesia Periode 2006-2010.

Selain itu, hasil penelitian ini juga sejalan dengan penelitian sebelumnya yang dilakukan oleh Cerpen Naibaho (2010) yang hasilnya secara parsial variabel Return on Equity (ROE) berpengaruh positif dan signifikan terhadap variabel Harga Saham. Serta penelitian yang dilakukan oleh Donny Siahaan (2011) yang hasilnya ROE mempunyai pengaruh positif dan signifikan terhadap harga saham. Dengan demikian dapat semakin tinggi nilai Return on Equity maka akan semakin tinggi pula harga saham dan sebaliknya semakin rendah nilai Return on Equity maka harga saham akan semakin rendah pula.

3) Hasil penelitian ini diperkuat oleh kajian teori dan hasil penelitian yang relevan. Berdasarkan teori yang dikemukakan Purwanta dan Fakhrudin (2006: 101) faktor-faktor yang 


\section{Jurnal Nominal / Volume I Nomor I / Tahun 2012}

mempengaruhi harga saham yaitu terdiri dari Debt Equity Ratio, Dividend per Share, Return on Investment, Net Profit Margin, Return on Equity dan Earning per Share. Menurut Nathaniel (2008: 23) Net Profit Margin (NPM) melaporkan kemampuan perusahaan menghasilkan laba dari tingkat penjualan tertentu. Rasio ini menginterpretasikan tingkat efisiensi perusahaan, yakni sejauh mana kemampuan perusahaan menekan biaya-biaya yang ada di perusahaan pada periode tertentu. Selain itu, menurut Indra Bastian dan Suhardjono (2006: 299) Net Profit Margin adalah perbandingan antara laba bersih dengan penjualan bersih. Semakin besar NPM menunjukkan kinerja perusahaan yang produktif untuk memperoleh laba yang tinggi melalui tingkat penjualan tertentu serta kemampuan perusahaan yang baik dalam menekan biaya-biaya operasionalnya. Hal ini meningkatkan kepercayaan investor untuk menanamkan modalnya pada perusahaan tersebut sehingga permintaan akan saham perusahaan tersebut meningkat yang otomatis diikuti dengan naiknya harga saham tersebut. Teori tersebut semakin memperkuat hasil penelitian ini yaitu terdapat Net Profit Margin berpengaruh positif dan signifikan terhadap Harga Saham Perusahaan Industri Manu -faktur yang Tercatat di Bursa Efek Indonesia Periode 2006-2010.

Selain itu, hasil penelitian ini juga sejalan dengan penelitian yang dilakukan Santy Sitohang (2010) yang berjudul yang hasilnya secara parsial variabel Net Profit Margin berpengaruh positif dan signifikan terhadap harga saham perusahaan manufaktur yang terdaftar di BEI. Serta penelitian yang dilakukan oleh
Donny Siahaan (2011) yang hasilnya secara parsial variabel NPM berpengaruh positif dan signifikan terhadap harga saham. Dengan demikian dapat dikatakan semakin tinggi nilai Net Profit Margin maka akan semakin tinggi pula harga saham dan sebaliknya semakin rendah nilai Net Profit Margin maka harga saham jugan semakin rendah.

4) Hasil penelitian ini diperkuat oleh kajian teori. Berdasarkan teori yang dikemukakan Purwanta dan Fakhrudin (2006: 101) faktor-faktor yang mempengaruhi harga saham yaitu terdiri dari Debt Equity Ratio, Dividend per Share, Return on Investment, Net Profit Margin, Return on Equity dan Earning per Share. Teori semakin memperkuat hasil penelitian ini, yaitu Dividend per Share, Return on EquitydanNet Profit Margin berpengaruhpositifdan signifikan secara bersama-sama (simultan) terhadap HargaSaham Perusahaan Industri Manufaktur yang Tercatat di Bursa Efek Indonesia Periode 2006-2010.

Terbuktinya hipotesis keempat yang menyatakan Dividend per Share, Return on Equity dan Net Profit Margin berpengaruh positif secara bersama-sama (simultan) terhadap Harga Saham Perusahaan Industri Manu -faktur yang Tercatat di Bursa Efek Indonesia Periode 2006-2010, berarti dengan demikian dapat dikatakan bahwa semakin tinggi Dividend per Share, Return on Equity dan Net Profit Margin maka akan semakin tinggi pula Harga Saham dan sebaliknya apabila nilai Dividend per Share, Return on Equity dan Net Profit Margin semakin rendah maka Harga Saham akan semakin rendah pula. 


\section{Jurnal Nominal / Volume I Nomor I / Tahun 2012}

\section{KESIMPULAN DAN SARAN}

\section{Kesimpulan}

Berdasarkan sampel penelitian yang diperoleh dari hasil analisis yang dilakukan maka dapat ditarik kesimpulan sebagai berikut:

1. Dividend per Shareberpengaruh positif dan signifikan terhadap Harga SahamPerusahaan Industri Manufaktur yang tercatat di Bursa Efek Indonesia Periode 2006-2010.

2. Return on Equity pengaruh positif dan signifikan terhadap Harga SahamPerusahaan Industri Manufaktur yang tercatat di Bursa Efek Indonesia Periode 2006-2010.

3. Net Profit Marginpengaruh positif dan signifikanterhadap Harga SahamPerusahaan Industri Manufaktur yang tercatat di Bursa Efek Indonesia Periode 2006-2010.

4. Dividend per Share, Return on Equity dan Net Profit Marginpengaruh positif dan signifikan secara bersama-sama (simultan) terhadap Harga SahamPerusahaan Industri Manufaktur yang tercatat di Bursa Efek Indonesia Periode 2006-2010.

\section{Keterbatasan Penelitian}

Peneliti dalam melaksanakan penelitian mempunyai keterbatasan yang mungkin dapat menimbulkan bias, antara lain sebagai berikut:

1. Karena keterbatasan waktu dan dana, peneliti hanya menguji faktor internal yang mempengaruhi harga saham yaitu Dividend per Share, Return on Equity dan Net Profit Margin sehingga peneliti tidak sempat menguji faktor eksternal yang mempengaruhi harga saham.

2. Terbatasnya sampel penelitian dikarenakan masih sedikit perusahaan yang membagikan dividen selama tahun 2006-2010.

3. Karena keterbatasan waktu dan dana, peneliti hanya melakukan penelitian selama lima tahun terakhir yaitu periode 2006-2010 sehingga kurang mencerminkan keadaan pasar modal yang sebenarnya.

\section{Saran}

Berdasarkan hasil penelitian dan kesimpulan di atas, maka dapat diberikan saran-saran berikut:

\section{Bagi Investor}

Sebelum memutuskan untuk menanamkan dananya pada suatu perusahaan, hendaknya mempertimbangkan berbagai macam faktor yang mempengaruhi harga saham. Investor hendaknya tidak hanya mempertimbangkan laba perusahaan tersebut, tetapi juga faktorfaktor yang lain, seperti Dividend per Share, Return on Equity dan Net Profit Margin.

\section{Bagi Emiten}

Pihak perusahaan sebaiknya meningkatkan kinerja keuangan maupun kinerja manajemen perusahaan setiap tahunnya sehingga persepsi investor terhadap prospek kinerja perusahaan di masa depan dapat dijaga dengan baik. Kinerja keuangan perusahaan tersebut dapat ditunjukkan dengan meningkatkan Dividend per Share. Dalam meningkatkan Dividend per Share tersebut caranya dengan meningkatkan laba bersihnya, karena Dividend per Share sendiri berasal dari laba bersih perusahaan. 
Jurnal Nominal / Volume I Nomor I / Tahun 2012

Selain itu perusahaan perlu memiliki kebijakan dividen yang tepat dalam membayarkan Dividend per Share. Sehingga proporsi antara dividen yang akan dibayarkan dan laba yang ditahan harus seimbang. Selain itu, perusahaan perlu menaikkan nilai ROE yaitu dengan cara perusahaan mengelola modal dari pemegang saham lebih efektif dan efisien. Perusahaan dapat meniadakan atau pun menghilangkan aktivitas yang tidak diperlukan untuk mengefektifkan modal dari pemegang saham sehingga laba yang akan didapatkan juga semakin tinggi. Selain itu, untuk menaikkan nilai NPM, perusahaan sebaiknya lebih efisien dan efektif dalam menekan biaya operasional maupun biaya produksinya, contohnya perusahaan dapat lebih hemat serta selektif dalam memilih bahan baku untuk produksi. Selanjutnya, perusahaan juga dapat meningkatkan penjualan nya dengan cara menambah volume produk penjualannya atau meningkatkan harga produk penjualannya. Hal tersebut dapat meningkatkan ketertarikan dan kepercayaan investor untuk menanamkan dananya pada perusahaan pun dapat dipertahankan karena investor dapat menilai bahwa perusahaan tersebut cukup profitable.

\section{Bagi Peneliti Selanjutnya}

a. Peneliti selanjutnya dapat menggunakan faktor-faktor internal lainnya yang kemungkinan mempengaruhi harga saham selain Return on Equity dan Net Profit Margin, misalnya Return on Investment, Debt Equity ratio, Total Asset, Turn Over Ratio atau Growth Potential.

b. Peneliti selanjutnya dapat menggunakan faktor-faktor eksternal yang kemungkinan mempengaruhi harga saham seperti inflasi, tingkat suku bunga, pertumbuhan ekonomi Indonesia atau kurs valuta asing.

c. Peneliti selanjutnya dapat menggunakan periode penelitian selama 10 tahun terakhir, misalnya dari tahun 2000-2010 sehingga dapat mencerminkan keadaan pasar modal yang sebenarnya.

\section{E. DAFTAR PUSTAKA}

Annio Indah Lestari N, Muslich Lutfi dan Syahyunan. (2007). Pengaruh Faktor Fundamental dan Teknikal Terhadap Harga Saham Properti yang Terdaftar di Bursa Efek Jakarta. Jurnal Ekonomi, Bisnis dan Akuntansi. Vol. 2 No. 2: Hal. 87-109.

Ardin Sianipar. (2005). Pengaruh Faktor Fundamental Terhadap Harga Saham Industri Perbankan di Inonesia. Tesis. Magister Akuntansi Sekolah Pascasarjana Universitas Sumatera Utara.

Brigham, Eugene F. \& Joel F. Houston.(2006). Manajemen Keuangan. Jakarta: Erlangga.

Cerpen Naibaho. (2010). Pengaruh Dividend Per Share (DPS) dan Return On Equity (ROE) Terhadap Harga Saham Perusahaan Makanan dan Minuman yang tercatat di Bursa Efek Indonesia. Tesis. Magister Akuntansi Sekolah Pascasarjana Universitas Sumatera Utara.

Donny Siahaan. (2011). Analisis Pengaruh Return on Equity dan Net Profit Margin terhadap Harga Saham Perusahaan Industri Kimia dan Dasar yang Terdaftar di Bursa Efek Indonesia. Tesis. Magister Akuntansi Sekolah Pascasarjana Universitas Sumatera Utara. 
Jurnal Nominal / Volume I Nomor I / Tahun 2012

Eduardus Tandelilin. (2001). Analisis Investasi dan Manajemen Portofolio. Edisi Pertama. Yogyakarta: BPFE.

Endang Dwi Wahyuni. (2011). Kebijakan Dividen.

(http://www.endang.staff.umm.ac.id/ file s / B A B - I I - K E B I J A K A N DIVIDEN1.pdf, diakses 10 April 2012).

Felicia Elvira Sitohang. (2008). Pengaruh Economic Value Added, Market Value Added, Rasio Profitabilitas Terhadap Harga Saham. Tesis. Magister Manajemen Fakultas Ekonomika dan Bisnis Universitas Gadjah Mada.

Firmansyah Fakhruddin dan Hadianto. (2001). Manajemen Investasi Portofolio. Jakarta: Salemba Empat.

Gibson, James,L. (2003). Organisasi, Perilaku, Struktur dan Proses. Edisi ke-5. Cetakan ke-3. Jakarta: Erlangga.

Heriyati Chrisna. (2011). Pengaruh Return On Equity, Net Interest Margin dan Dividend Payout Terhadap Harga Saham Perbankan di Bursa Efek Indonesia. Tesis. Magister Akuntansi Sekolah Pascasarjana Universitas Sumatera Utara.

Imam Ghozali. (2007). Aplikasi Analisis Multivariate dengan Program SPSS. Semarang: Badan Penerbit Universitas Diponegoro.

Ina Rinati. (2001). Pengaruh Net Profit Margin (NPM, Return On Assets (ROA), Dan Return On Equity (ROE) Terhadap Harga Saham Perusahaan yang Tercantum dalam Indeks LQ45. Jurnal Ekonomi dan Manajemen. Vol. 1, No. 2: Hal. 119-131.

Indah Nurmalasari. (2002). Analisis Pengaruh Faktor Profitabilitas Terhadap Harga Saham Emiten LQ45 yang Tercatat di Bursa Efek Jakarta Periode 2005-2008. Jurnal Ekonomi dan Manajemen. Vol. 7 No.3: Hal. 67-98.

Indra Bastian dan Suhardjono. (2006). Akuntansi Perbankan. Edisi 1. Jakarta: Salemba Empat.
Joko Sulistyo. (2010). 6 Hari Jago SPSS17. Yogyakarta: Cakrawala.

Jogiyanto. (2008). Teori Portofolio dan Analisis Investasi. Edisi Ketiga. Yogyakarta: BPFE

Khalway, T. (2008). Inflasi dan Solusinya. Jakarta: Gramedia.

Lincolin Arsyad. (2004). Ekonomi Pembangunan. Yogyakarta: STIE YKPN.

Lukas Setia Atmaja. (2008). Manajemen Keuangan. Yogyakarta: Andi Offset.

Lumban Gaol Maskarni. (2010). Pengaruh Return On Assets, Return Equity, Price Earning Ratio Terhadap Harga Saham Perusahaan Manufaktur di BEI. Tesis. Magister Manajemen Sekolah Pascasarjana Universitas Sumatera Utara.

Nicky Nathaniel. (2008). Analisis Faktor-Faktor yang Mempengaruhi terurn Saham (Studi Pada Saham Real estate dan properti di Bursa Efek Indonesia Periode 20032006). Tesis. Magister Manajemen Program Pascasarjana Universitas Diponegoro.

Raja Lambas J. Panggabean. (2005). Analisis Perbandingan Korelasi EVA dan ROE Terhadap Harga Saham LQ45 di Bursa Efek Jakarta. Jurnal Manajemen San Bisnis. Vol. 3 No. 5: Hal. 01-19.

Rowland Bismark Fernando Pasaribu. (2008). Pengaruh Variabel Fundamental Terhadap Harga Saham Perusahaan Go Public di Bursa Efek Indonesia Periode 2003 -2006. Jurnal Ekonomi dan Bisnis. Vol. 2 No. 2: Hal. 101-113.

Sahata Pardomuan Sidabutar. (2007). Analisis Pengaruh Kepemilikan Institusi, Net Profit Margin, Debt To Equity Ratio dan Rsio-Rasio Bank terhadap Return On Equity. Tesis. Magister Manajemen Sekolah Pascasarjana Universitas Sumatera Utara. 
Santy Sitohang. (2010). Pengaruh Economic Value Added, Return On Assets, Return On Equity dan Earning Per Share Terhadap Harga Saham Perusahaan Manufaktur yang Tercatat di Bursa Efek Indonesia. Tesis. Magister Akuntansi Sekolah Pascasarjana Universitas Sumatera Utara.

Sawidji Widoatmodjo. (2005). Cara Sehat Investasi di Pasar Modal. Jakarta: PT. Jurnalindo Aksara Grafika.

Suad Husnan dan Enny Pudjiatuti. (2004). DasarDasar Manajemen Keuangan. Yogyakarta: UPP AMP YKPN

Sugiyono. (2008). Statistika Untuk Penelitian. Bandung: Alfabeta.

Sunariyah. (2004). Pengantar Pengetahuan Pasar Modal. Edisi Keempat. Yogyakarta: AMP YKPN.

Susan Grace Veranita Nainggolan. (2008). Pengaruh Variabel Fundamnetal Terhadap Harga Saham Perusahaan Manufaktur yang Terdaftar di Bursa Efek Indonesia. Tesis. Akuntansi Sekolah Pascasarjana Universitas Sumatera Utara.

Susan Irawaty. (2006). Manajemen Keuangan. Bandung: Alfabeta.
Sutrisno Hadi. (2004). Analisis Regresi. Yogyakarta: Andi Offset.

Sutrisno. (2003). Manajemen Keuangan (Teori, Konsep, dan Aplikasi).Edisi Pertama. Cetakan Kedua. Yogyakarta: EKONISIA

Suyoto. (2010). Ramai-Ramai Investasi di Manufaktur. Kompas. 7 Juli 2010.

Taranika Intan. (2009). Pengaruh Dividend Per Share, Risiko Sistematis dan Inflsi Terhadap Harga Saham Industri Tekstil di Bursa Efek Indonesia. Tesis. Magister Akuntansi Sekolah Pascasarjana Universitas Sumatera Utara.

Warren, Carl S., James M. Reeve dan Philip E. Fees. (2009). Intermediate Accounting. Edisi 20. Jilid III. Alih Bahasa Alfonsus Sirait dan Helda Gunawan. Jakarta: Erlangga.

Weston, J. Fred \& Brigham. (2003). Dasar-Dasar Manajemen Keuangan. Jakarta: Erlangga.

Weston, J. Fred \& Copeland. (2001). Manajemen Keuangan. Jakarta : Erlangga.

Van Horne, James C. (2005). Accounting Economics. Jakarta: PT. Gramedia Pustaka Utama. 